\title{
Total anomalous pulmonary venous drainage to persistent left superior vena cava: a unique configuration
}

\author{
Mumun Sinha, Niraj N Pandey, Arun Sharma
}

Department of Cardiovascular Radiology and Endovascular Interventions, All India Institute of Medical Sciences, New Delhi, India

Correspondence to Dr Arun Sharma,

drarungautam@gmail.com

Accepted 11 September 2019

\section{DESCRIPTION}

A 1-year-old child underwent cardiac CT angiography (CTA) for further characterisation of a complex congenital cardiac defect. Review of CTA multiplanar reconstructed and volume-rendered images revealed thoracoatrial right isomerism with the presence of bilateral superior vena cavae (SVC) and an intercommunicating vein. The right superior pulmonary vein, right inferior pulmonary vein and left inferior pulmonary vein formed a common channel (*) which received the left superior pulmonary vein just before draining into the left superior vena cava (LSVC) (figure 1A-D). The LSVC was seen to directly drain into the left atrium with the absence of coronary sinus (figure 1E,F). The other concomitant structural defects included the presence of a double-outlet right ventricle, ventricular septal defect and pulmonary stenosis.

Embryologically, the pulmonary venous plexus (which surrounds the lung bud and is contiguous with the splanchnic venous plexus) forms a connection with the pulmonary veins which arise from the dorsal wall of sinus venosus and in this process, its connections with the cardinal and umbilicovitelline veins disappear. Abnormal

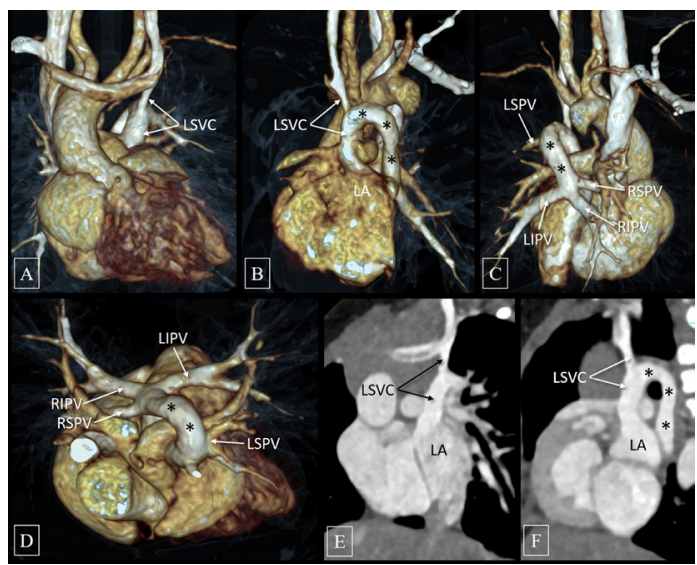

Check for updates

(C) BMJ Publishing Group Limited 2019. No commercial re-use. See rights and permissions. Published by BMJ.

To cite: Sinha M, Pandey NN Sharma A. BMJ Case

Rep 2019;12:e231898.

doi:10.1136/bcr-2019-

231898
Figure 1 Volume rendered images (A-D) depict the RSPV, RIPV and LIPV forming a common channel ${ }^{*}$ ) which receives the (LSPV just before draining into the LSVC. Maximum intensity projection images in the oblique coronal (E) and oblique sagittal (F) planes demonstrate the LSVC draining directly into the LA. LA, left atrium; LIPV, left inferior pulmonary vein; LSPV, left superior pulmonary vein; LSVC, left superior vena cava; RIPV, right inferior pulmonary vein; RSPV, right superior pulmonary vein persistence of these communications gives rise to partial or total anomalous pulmonary venous connection (TAPVC). ${ }^{1}$ If these connections coexist along with abnormal persistence of the left precardinal vein, an extremely rare configuration of anomalous (total or partial) pulmonary venous drainage into the persistent LSVC may arise. Though various patterns of communication of pulmonary veins and persistent LSVC have been explained embryologically and classified by Snellen $e t$ al, there are only anecdotal reports demonstrating this anomalous drainage pattern on cardiac CTA. ${ }^{2}$ Although Maki et al recently described a case of partial anomalous pulmonary venous drainage into persistent LSVC on cardiac CTA, to the best of our knowledge, TAPVC into the LSVC on CTA is hitherto unreported. ${ }^{3}$ Also, even though TAPVC is the most common type of pulmonary venous drainage anomaly associated with right isomerism, its connection with the persistent LSVC is only rarely reported in the literature.

\section{Learning points}

- Abnormal persistence of embryological connections between the pulmonary venous plexus and the cardinal and umbilicovitelline veins give rise to partial or total anomalous pulmonary venous connections.

- Although total anomalous pulmonary venous connection is the most common type of pulmonary venous drainage anomaly associated with right isomerism, its connection with the persistent left superior vena cava is rare.

Contributors MS: participated sufficiently in the conception of the idea, development of the intellectual content, design, writing and final approval of the manuscript. NNP: participated sufficiently in the conception of the idea, development of the intellectual content, design, writing and final approval of the manuscript. AS: participated sufficiently in the conception of the idea, development of the intellectual content, design, writing and final approval of the manuscript.

Funding The authors have not declared a specific grant for this research from any funding agency in the public, commercial or not-for-profit sectors.

Competing interests None declared.

Patient consent for publication Parental/guardian consent obtained.

Provenance and peer review Not commissioned; externally peer reviewed. 


\section{REFERENCES}

1 Pandey NN, Sharma A, Jagia P. Imaging of anomalous pulmonary venous connections by multidetector $\mathrm{CT}$ angiography using third-generation dual source $\mathrm{CT}$ scanner. $\mathrm{Br}$ J Radiol 2018;91:20180298.
2 Snellen $\mathrm{HA}$, van Ingen $\mathrm{HC}$, Hoefsmit EC. Patterns of anomalous pulmonary venous drainage. Circulation 1968;38:45-63.

3 Maki R, Miyajima M, Mishina T, et al. Left upper pulmonary vein connected to the persistent left superior vena cava and the left atrium. Gen Thorac Cardiovasc Surg 2019;67:723-5.

Copyright 2019 BMJ Publishing Group. All rights reserved. For permission to reuse any of this content visit https://www.bmj.com/company/products-services/rights-and-licensing/permissions/

BMJ Case Report Fellows may re-use this article for personal use and teaching without any further permission.

Become a Fellow of BMJ Case Reports today and you can:

- Submit as many cases as you like

- Enjoy fast sympathetic peer review and rapid publication of accepted articles

- Access all the published articles

- Re-use any of the published material for personal use and teaching without further permission

Customer Service

If you have any further queries about your subscription, please contact our customer services team on +44 (0) 2071111105 or via email at support@bmj.com.

Visit casereports.bmj.com for more articles like this and to become a Fellow 